\title{
Pollution status of North Sea sediments - an international integrative study
}

\author{
Peter M. Chapman
}

EVS Consultants, 195 Pemberton Avenue, North Vancouver, British Columbia, Canada V7P 2R4

\begin{abstract}
This paper describes the pollution status of North Sea sediments, and is based on results of sediment testing conducted during the Bremerhaven Workshop designed to test various methods (chemical and biological) for assessing the status of North Sea waters, sediments and biota. Testing comprised 2 transects, one down current from an abandoned drilling site, and the other across the German Bight from the mouth of the Elbe northwest. Sediment methods focused on toxicity testing, chemical analyses, and measures of in situ benthic community structure. Together these 3 methods comprise the Sediment Quality Triad. Using the Triad in a burden-of-evidence approach, it was determined that sediments nearest the Elbe are moderately polluted (pollution is defined as contamination, toxicity and benthic community alteration), and that sediments offshore and at Dogger Bank are unpolluted. Sediments nearest the drilling site show evidence of relatively low level toxicity and benthic community alteration. Limited chemical measurements did not indicate contamination. Observed laboratory toxicity and alterations in benthic infauna community structure may be due to unmeasured toxic chemicals. Anticipated effects due to drilling were not observed and appear to have been ameliorated by natural deposition of clean sediment. North Sea sediments away from point sources of pollution (e.g. coastal areas, drilling platforms) are expected to be unpolluted. Lesions in bottom fish in such offshore areas (e.g. the Dogger Bank) cannot be attributed to sediment pollution in these areas, but if they are truly indicative of anthropogenic pollution, could be due to other factor(s) such as exposure of planktonic larvae to sea surface microlayer chemical contamination and toxicity. Integrative assessments such as the Triad are essential for adequately assessing the status of European marine ecosystems. Although relatively expensive, such complete studies determine and prioritise problem areas such that managers, regulators and the public have access to the best possible information for decisionmaking and resource allocation.
\end{abstract}

\section{INTRODUCTION}

In March 1990, as part of the Bremerhaven Workshop, a variety of sediment assessment methods were applied to 2 transects along gradients of expected chemical contamination in the North Sea (see Stebbing \& Dethlefsen 1992). One transect comprised 7 stations at increasing distances down-current from an abandoned oil-drilling site off the Dutch coast. The other transect comprised 9 stations at increasing distances from the mouth of the Elbe River, Germany, out to the Dogger Bank. The overall aim of the workshop was to compare available biological effects monitoring techniques for marine pollution. A secondary aim was to determine the most suitable techniques for such monitoring in Europe.
The variety of sediment assessment methods used allowed for an integrative assessment (Chapman et al. 1992a) of the pollution status of the tested sediments, and an extrapolation to include North Sea sediments in general. In particular, the Sediment Quality Triad approach and concept was applied to sediment toxicity, chemical contamination and benthic infaunal community structure data. The Triad is an effects-based approach to describing sediment quality (Long \& Chapman 1985. Chapman 1986a, 1989, Chapman et al. 1987a, b, 1991a, b, Long 1989a, Cross et al. 1991, Alden 1992), which is described in detail by Chapman (1990, 1992).

This paper uses data and the results of other workshop studies to determine the pollution status of the tested sediments. Pollution is defined as chemical con- 
Table 1 Ratio-to-Reference (RTR) values for the drilling site stations. Outermost station (5000 m) used as reference; mean $(n=3)$ total sediment concentrations used in calculation except for polyaromatic hydrocarbons, PAH $(n=1)$, see text

\begin{tabular}{|c|c|c|c|c|c|c|c|}
\hline \multirow[t]{3}{*}{ Contaminant } & \multicolumn{7}{|c|}{ Station and distance from platform } \\
\hline & A & B & C & D & E & F & $\mathrm{G}$ \\
\hline & $0 \mathrm{~m}$ & $125 \mathrm{~m}$ & $250 \mathrm{~m}$ & $500 \mathrm{~m}$ & $1000 \mathrm{~m}$ & $2500 \mathrm{~m}$ & $5000 \mathrm{~m}$ \\
\hline \multicolumn{8}{|l|}{ Metals } \\
\hline As & 1.4 & 1.2 & 0.8 & 0.9 & 1.1 & 0.9 & 1.0 \\
\hline $\mathrm{Cd}$ & 1.4 & 1.0 & 0.9 & 0.9 & 0.4 & 0.9 & 1.0 \\
\hline $\mathrm{Cu}$ & 1.4 & 5.1 & 1.0 & 1.0 & 0.5 & 0.9 & 1.0 \\
\hline $\mathrm{Hg}$ & 1.3 & 1.2 & 0.5 & 0.9 & 0.5 & 0.8 & 1.0 \\
\hline $\mathrm{Pb}$ & 1.0 & 1.1 & 1.1 & 0.9 & 0.5 & 0.9 & 1.0 \\
\hline $\mathrm{Zn}$ & 0.9 & 1.0 & 0.8 & 0.9 & 0.7 & 0.9 & 1.0 \\
\hline Mean & 1.2 & 1.8 & 1.0 & 0.9 & 0.6 & 0.9 & 1.0 \\
\hline \multicolumn{8}{|l|}{ Total hydrocarbons (HC) } \\
\hline by UVF & 1.4 & 1.4 & 1.2 & 1.1 & 0.6 & 1.0 & 1.0 \\
\hline by $\mathrm{GC}$ & 45.2 & 3.2 & 5.5 & 40.2 & 1.2 & 0.5 & 1.0 \\
\hline Mean & 23.3 & 2.3 & 3.4 & 20.6 & 0.9 & 0.8 & 1.0 \\
\hline \multicolumn{8}{|l|}{ Low mol wt PAH (LPAH) } \\
\hline Naphthalene & 0.5 & 1.0 & 0.8 & 0.9 & 0.6 & 0.8 & 1.0 \\
\hline Methyl naphthalene & $<0.2$ & 1.1 & $<0.2$ & 1.0 & 0.6 & 1.5 & 1.0 \\
\hline Dimethyl naphthalene & $<0.1$ & 1.4 & 0.9 & 1.4 & 0.6 & $<0.1$ & 1.0 \\
\hline Trimethyl naphthalene & $<0.1$ & 1.6 & 1.0 & 1.2 & 0.5 & 1.6 & 1.0 \\
\hline Phenanthrene & 0.8 & 0.9 & 0.7 & 1.0 & 0.4 & 0.8 & 1.0 \\
\hline Methyl phenanthrene & 0.8 & 0.9 & 0.9 & 1.2 & 0.5 & 0.9 & 1.0 \\
\hline Anthracene & 1.1 & 1.1 & 0.9 & 1.6 & 0.5 & 1.1 & 1.0 \\
\hline Mean & $<0.5$ & 1.1 & 0.8 & 1.2 & 0.5 & $<1.0$ & 1.0 \\
\hline \multicolumn{8}{|l|}{ High mol. wt PAH (HPAH) } \\
\hline Fluoranthene & $<5.4$ & $<7.6$ & $<5.4$ & $<8.6$ & $<3.2$ & $<7.6$ & 1.0 \\
\hline Pyrene & $<4.8$ & $<6.6$ & $<4.8$ & $<7.0$ & $<2.6$ & $<5.8$ & 1.0 \\
\hline Benz(a)anthracene & 0.2 & 0.2 & 0.2 & 0.2 & $<0.1$ & 0.2 & 1.0 \\
\hline Chrysene + triphenylene & 0.1 & 0.2 & 0.1 & 0.2 & 0.1 & 0.1 & 1.0 \\
\hline Benzofluoranthenes & $<2.4$ & $<1.0$ & $<6.0$ & $<6.4$ & $<3.6$ & $<6.6$ & 1.0 \\
\hline Benzo(e)pyrene & $<1.1$ & $<1.0$ & $<1.6$ & $<2.4$ & $<1.5$ & $<1.9$ & 1.0 \\
\hline Benzo(a)pyrene & $<1.0$ & $<1.0$ & $<1.0$ & $<1.4$ & $<1.0$ & $<1.0$ & 1.0 \\
\hline Perylene & $<1.0$ & $<1.0$ & $<1.0$ & $<1.0$ & $<1.0$ & $<1.0$ & 1.0 \\
\hline Mean & $<2.0$ & $<2.3$ & $<2.5$ & $<3.4$ & $<1.6$ & $<3.0$ & 1.0 \\
\hline
\end{tabular}

tamination associated with toxicity and in situ alteration of resident communities. Extrapolations are made to the other major aspects of the workshop: water quality (water column and microlayer chemistry and toxicity), and dab Limanda limanda pathology. Recommendations are made on the usefulness and need for integrative assessments to determine the health of European marine ecosystems.

\section{SEDIMENT CHEMISTRY}

Sediment chemical contamination was determined for 3 basic groups of chemicals: metals, polyaromatic hydrocarbons (PAH) and PCBs (Cofino et al. 1992). Analyses did not include all low and high molecular weight PAH of possible toxicological concern (e.g. LPAH: acenaphthylene, acenaphthene, fluorene;
HPAH: indeno(1,2,3-cd)pyrene; dibenzo(a,h)anthracene; benzo( $g, h, i)$ perylene). However, the PAH were reasonably well characterised as a sufficient number of potentially co-varying PAH were analysed. More significant omissions include ammonia (Ankley et al. 1990), chlorobenzenes, pesticides, methylated and chlorinated phenols, and alcohols (Chapman et al. 1982).

Sediment chemistry data for contaminants measured along both transects were converted to Ratio-toReference values (RTR: Chapman et al. 1987b, Chapman 1990 ) to provide clarity in comparisons and data presentation (Tables $1 \& 2$ ). PCBs were only measured along the German Bight transect; trends there followed those of the other measured contaminants (Cofino et al. 1992). Individually measured parameters [chemical contaminant concentrations (Cofino et al. 1992), percent sand and loss on ignition [Chapman et al. $1992 \mathrm{~b}$ |) were divided by reference station values for 
Table 2. Ratio-to-Reference (RTR) values for the German Bight stations. Outermost station (Stn 9) used as reference; mean $(n=3)$ total sediment concentrations used in calculation except for polyaromatic hydrocarbons, PAH $(n=1)$, see text

\begin{tabular}{|c|c|c|c|c|c|c|c|c|c|}
\hline \multirow[t]{2}{*}{ Contaminant } & \multicolumn{9}{|c|}{ Station } \\
\hline & 1 & 2 & 3 & 4 & 5 & 6 & 7 & 8 & 9 \\
\hline \multicolumn{10}{|l|}{ Metals } \\
\hline As & 14.2 & 7.4 & 8.6 & 5.0 & 4.6 & 4.2 & 2.8 & 3.8 & 1.0 \\
\hline $\mathrm{Cd}$ & 222.7 & 91.7 & 100.3 & 44.0 & 40.7 & 5.7 & 1.3 & 1.0 & 1.0 \\
\hline $\mathrm{Cu}$ & 12.4 & 4.5 & 5.7 & 2.6 & 4.0 & 1.9 & 1.5 & 2.1 & 1.0 \\
\hline $\mathrm{Hg}$ & 73.0 & 17.0 & 20.5 & 7.5 & 4.5 & 2.3 & 1.0 & 1.0 & 1.0 \\
\hline $\mathrm{Pb}$ & 13.4 & 5.4 & 6.4 & 3.7 & 3.2 & 2.5 & 1.9 & 1.4 & 1.0 \\
\hline $\mathrm{Zn}$ & 42.7 & 45.3 & 32.7 & 22.9 & 17.5 & 10.7 & 7.1 & 3.4 & 1.0 \\
\hline Mean & 63.1 & 28.6 & 29.0 & 14.3 & 12.4 & 4.6 & 2.6 & 2.1 & 1.0 \\
\hline \multicolumn{10}{|l|}{ Total hydrocarbons (HC) } \\
\hline by UVF & 52.7 & 20.6 & 25.0 & 15.2 & 17.1 & 19.6 & 11.2 & 3.4 & 1.0 \\
\hline by $\mathrm{GC}$ & 51.0 & 114.0 & 4.5 & 0.5 & 5.5 & 14.0 & 4.5 & 3.5 & 1.0 \\
\hline Mean & 51.8 & 67.3 & 14.8 & 7.8 & 11.3 & 16.8 & 7.8 & 3.4 & 1.0 \\
\hline \multicolumn{10}{|l|}{ Low mol. wt PAH (LPAH) } \\
\hline Naphthalene & $<86$ & $<25$ & $<33$ & $<14$ & $<6.5$ & $<14$ & $<5$ & $<1.6$ & 1.0 \\
\hline Methyl naphthalene & $<24$ & $<7.8$ & $<11.6$ & $<5.4$ & $<3.6$ & $<10.4$ & $<4.0$ & $<1.2$ & 1.0 \\
\hline Dimethyl naphthalene & $<34$ & $<11$ & $<12$ & $<7.7$ & $<5.7$ & $<13$ & $<6.5$ & $<2$ & 1.0 \\
\hline Trimethyl naphthalene & $<22$ & $<6.5$ & $<8.2$ & $<5.5$ & $<5.0$ & $<7.4$ & $<3.0$ & $<1.0$ & 1.0 \\
\hline Phenanthrene & 117 & 27.5 & 37.5 & 17.5 & 14.2 & 20.8 & 6.6 & 3.1 & 1.0 \\
\hline Methyl phenanthrene & $<15.4$ & $<4.2$ & $<5.2$ & $<3.4$ & $<3.2$ & $<5$ & $<1.7$ & $<1.0$ & 1.0 \\
\hline Anthracene & $<41$ & $<8.8$ & $<9.9$ & $<4.7$ & $<3.3$ & $<4.4$ & $<1.0$ & $<1.0$ & 1.0 \\
\hline Mean & $<48.5$ & $<13.1$ & $<6.8$ & $<8.3$ & $<5.9$ & $<10.7$ & $<4.0$ & $<1.6$ & 1.0 \\
\hline \multicolumn{10}{|l|}{ High mol. wt PAH (HPAH) } \\
\hline Fluoranthene & $<140$ & $<55$ & $<73$ & $<27$ & $<25$ & $<30$ & $<8.3$ & $<3.0$ & 1.0 \\
\hline Pyrene & $<110$ & $<42$ & $<50$ & $<24$ & $<20$ & $<29$ & $<8.0$ & $<2.5$ & 1.0 \\
\hline Benz(a)anthracene & $<36$ & $<12$ & $<18$ & $<7.7$ & $<6.6$ & $<7.9$ & $<2.5$ & $<1.0$ & 1.0 \\
\hline Chrysene + triphenylene & $<54$ & $<89$ & $<26$ & $<11$ & $<10$ & $<13$ & $<4.2$ & $<1.4$ & 1.0 \\
\hline Benzofluoranthenes & $<92$ & $<27$ & $<40$ & $<22$ & $<18$ & $<25$ & $<11$ & $<1$ & 1.0 \\
\hline Benzo(e)pyrene & $<31$ & $<5.9$ & $<17$ & $<8.8$ & $<6.1$ & $<10$ & $<2.9$ & $<1$ & 1.0 \\
\hline Benzo(a)pyrene & $<18$ & $<4.1$ & $<9.0$ & $<4.7$ & $<2.8$ & $<7.1$ & $<1.2$ & $<1$ & 1.0 \\
\hline Perylene & $<49$ & $<12$ & $<17$ & $<6.8$ & $<4$ & $<3$ & $<1$ & $<1$ & 1.0 \\
\hline Mean & $<66.2$ & $<30.9$ & $<31.2$ & $<14$ & $<11.6$ & $<15.6$ & $<4.9$ & $<1.5$ & 1.0 \\
\hline
\end{tabular}

those same parameters. Reference stations (Stn 9 for the German Bight transect and Stn G used here for the drilling site transect) were farthest from sources, had lowest overall chemical contaminant concentrations, were not toxic in laboratory bioassays (Chapman et al. 1992b) and did not contain altered benthic infaunal communities which could have been due to chemical contamination (Kröncke \& Rachor 1992, Kröncke et al. 1992).

Summarised chemical contaminant data (Tables 1 \& 2) and sediment physical characteristics are compared in Fig. 1, as RTR values. Means were determined assuming that values less than detection limits were equal to those detection limits. The drilling site transect had highly uniform sediments, and generally similar concentrations of contaminants: metals and LPAH concentrations only varied within a factor of $2 ; \mathrm{HPAH}$ concentrations varied within a factor of 3.5. Total HC concentrations were more variable, up to a factor of 23.3. This variability in $\mathrm{HC}$ was attributable to $\mathrm{GC}$ analyses which were much more variable than UVF analyses, and showed no clear trend; very high concentrations were noted at $0 \mathrm{~m}$ (Stn A) and $500 \mathrm{~m}$ (Stn D) with much lower concentrations at all other stations. Oil concentrations in sediments in the centre of the drilling site were an order of magnitude lower than was measured in 1988, 1 yr after cessation of drilling (Daan et al. 1992).

The German Bight transect, in contrast, had marked differences in sediment characteristics and contaminant concentrations (Fig. 1). Highest concentrations of contaminants and finest sediments were found at Stn 1; contaminant concentrations decreased seaward as did the sediment fines and organic carbon content. Contaminant concentrations were on the order of $50 \times$ greater at Stn 1 than at Stn 9. 

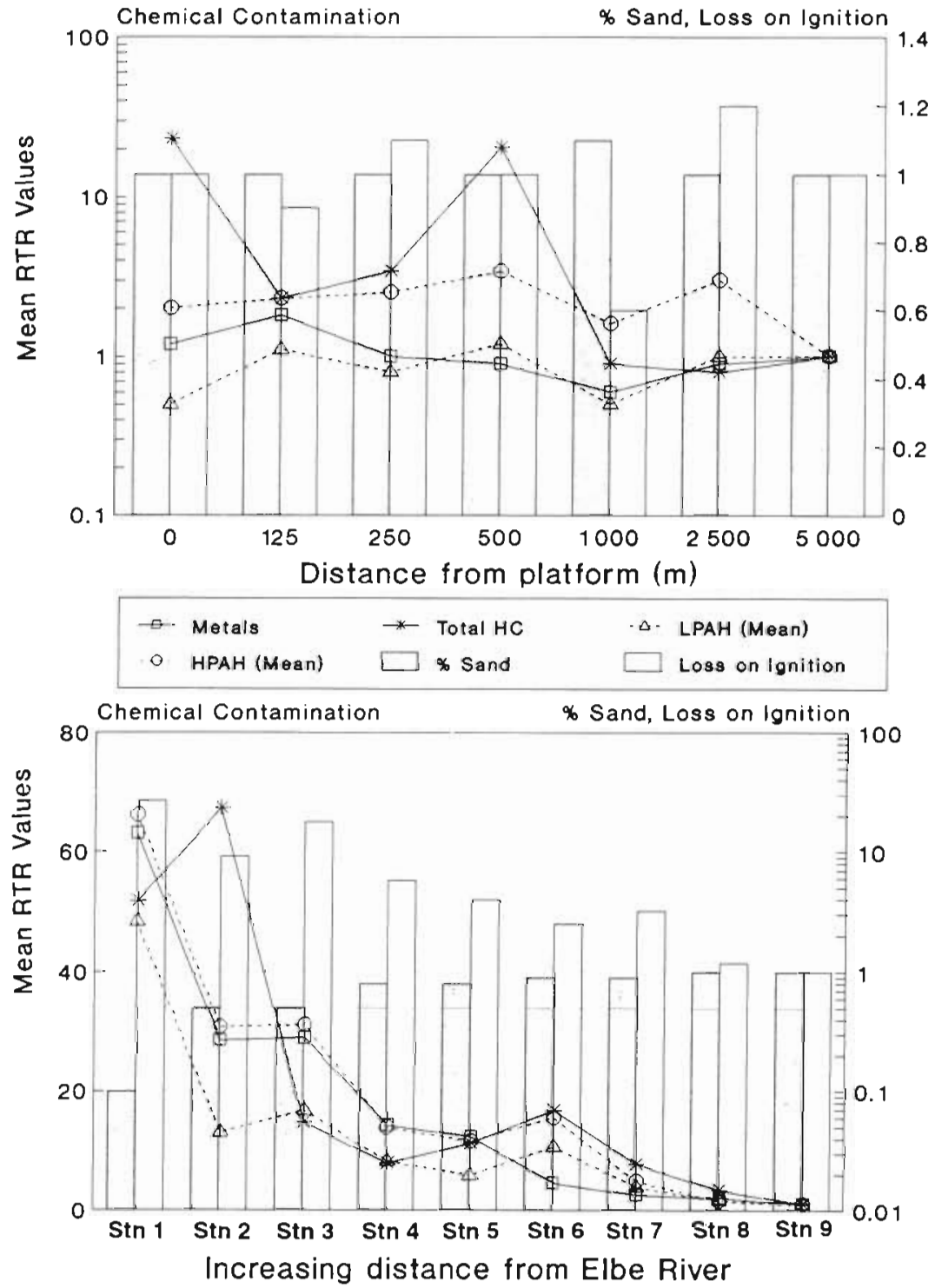

Fig. 1. Sediment chemical contaminant data and sediment composition for (A) drilling area, and (B) German Bight. RTR: Ratio to Reference; outermost station (5000 m and Stn 9) of each gradient used as reference; for explanation, see text

ing purposes (Chapman 1989) and divergence is as common as consensus among different approaches (Long 1989b), the extent to which chemical concentrations exceed sediment quality values coupled with A measured effects does not necessarily indicate cause and effect. Although future research at the inner German Bight stations could usefully focus on chemicals such as mercury, lead and dimethylnaphthalene which exceed more than one sediment quality value, not all chemicals which could have contributed to the observed toxicity were analysed.

\section{SEDIMENT TOXICITY}

Sediment toxicity results have been summarised by Chapman et al. (1992b). Trends in toxicity are further summarised in Tables 4 \& 5. Complete agreement between different toxicity tests only occurs when sediments are either highly toxic, or non-toxic (Chapman 1986b, 1988, 1989). The drilling site and German Bight sediments both had intermediate to low toxicity, hence the observed differences between test results are expected.

Overall, there was a general trend of higher toxicity closest to sources on both transects (Stns A \& 1). This trend is best

In order to put the measured contaminant concentrations into perspective, highest concentrations of individual chemicals are compared to available sediment quality values in Table 3 . This comparison indicates that none of the sediments would be expected to be highly toxic (as determined by toxicity testing). Even the highest measured chemical concentrations rarely exceeded the sediment quality values, and then only at lower effects levels. Further, the extent to which concentrations exceeded sediment quality values only ranged from 1.1 to $1.8 \times_{i}$ except for mercury where concentrations were $2.9 \times$ higher. Because sediment quality values are useful primarily for screen- seen in primary toxicity test end-points (Table 4), which are routinely accorded more weight than secondary end-points (Chapman 1988). Thain (1992) demonstrated a similar trend along the German Bight transect based on oyster larvae $24 \mathrm{~h}$ sediment elutriate toxicity tests. These tests were conducted on shipboard during a cruise 1 wk earlier than all other sediment tests (Butler et al. 1992). Some of the toxicity tests, which did not follow the contamination-toxicity trend, experienced difficulties in meeting quality assurance/quality control (QA/QC) requirements (Chapman et al. 1992b). All tests showing the contamination-toxicity trend met the $\mathrm{QA} / \mathrm{QC}$ requirements. 


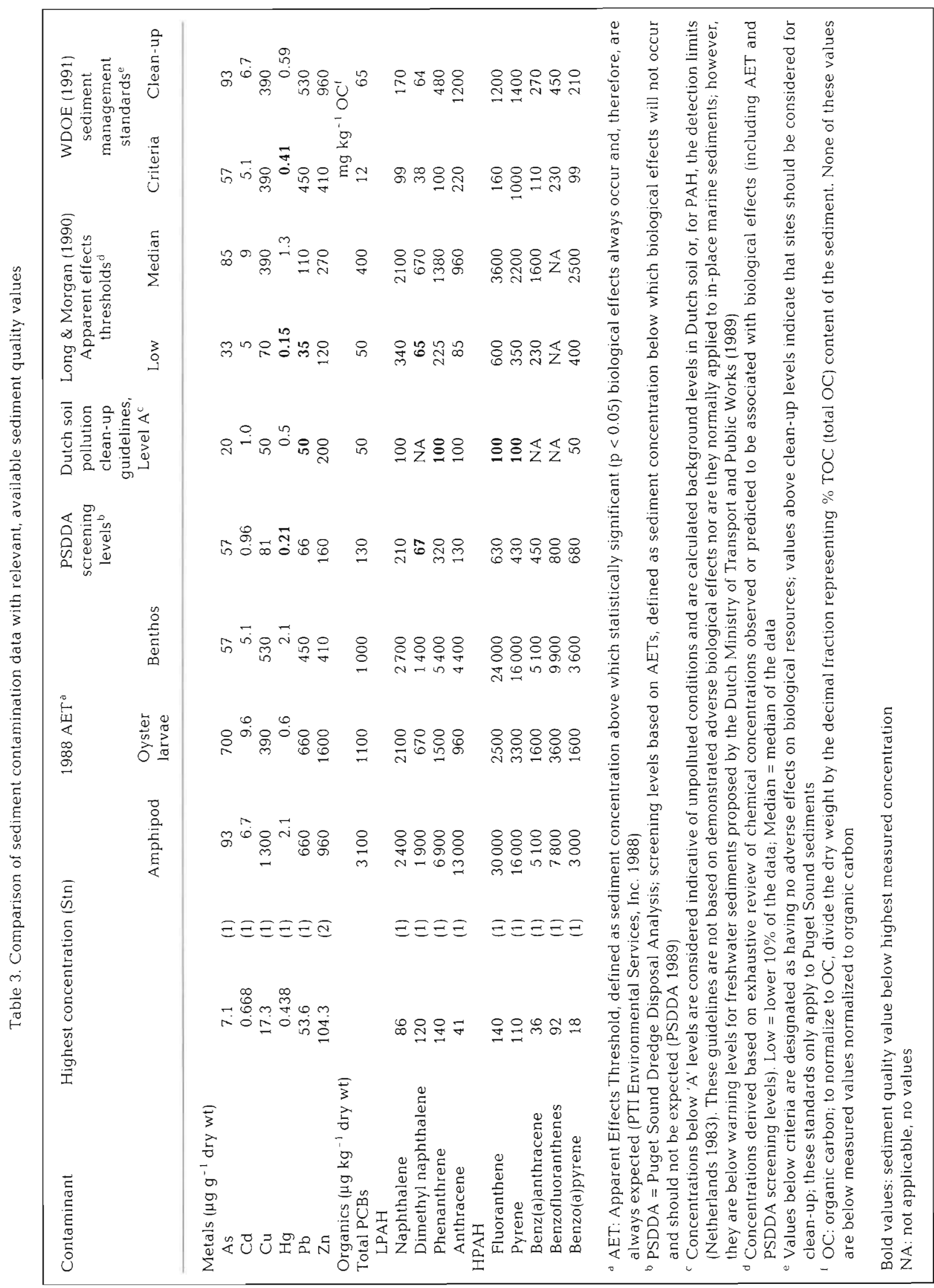


Table 4. Trends in sediment toxicity tests. Trends were determined visually and by data examination and are not necessarily statistical (cf. Chapman et al. 1992b)

\begin{tabular}{|c|c|c|c|c|c|}
\hline \multirow[t]{2}{*}{ Investigators } & \multirow[t]{2}{*}{ Country } & \multirow[t]{2}{*}{ Test organism } & \multirow{2}{*}{$\begin{array}{l}\text { End-points } \\
\left({ }^{*}=\text { primary }\right)\end{array}$} & \multicolumn{2}{|c|}{ Results: trend of higher toxicity ${ }^{d}$} \\
\hline & & & & $\begin{array}{l}\text { At drilling site } \\
\text { near platform }\end{array}$ & $\begin{array}{c}\text { In German Bight } \\
\text { near Elbe R. }\end{array}$ \\
\hline Swartz & USA & $\begin{array}{l}\text { Rhepoxynius abronius } \\
\text { (amphipod) }\end{array}$ & $\begin{array}{l}\text { Survival } \\
\text { Reburial }\end{array}$ & $\begin{array}{l}\text { Yes } \\
\text { No trend }\end{array}$ & $\begin{array}{l}\text { Yes } \\
\text { No trend }\end{array}$ \\
\hline Chapman & Canada & $\begin{array}{l}\text { Rhepoxynius abronius } \\
\text { (amphipod) } \\
\text { Neanthes arenaceodentata } \\
\text { (polychaete) } \\
\text { Crassostrea gigas } \\
\text { (oyster) }\end{array}$ & $\begin{array}{l}\text { Survival } \\
\text { Avoidance } \\
\text { Reburial } \\
\text { Survival } \\
\text { Growth } \\
\text { Survival } \\
\text { Development. }\end{array}$ & $\begin{array}{l}\text { Yes } \\
\text { No trend } \\
\text { No trend } \\
\text { No trend } \\
\text { No trend } \\
\text { Yes } \\
\text { Yes }\end{array}$ & $\begin{array}{l}\text { Yes } \\
\text { No trend } \\
\text { No trend } \\
\text { Perhaps } \\
\text { Perhaps } \\
\text { Yes } \\
\text { Yes }\end{array}$ \\
\hline Roddie/Butler & UK & $\begin{array}{l}\text { Corophium volutator } \\
\text { (amphipod) } \\
\text { Crassostrea gigas } \\
\text { (oyster) } \\
\text { Microtox } \\
\text { (bacteria) }\end{array}$ & $\begin{array}{l}\text { Survival" } \\
\text { Immobilisation } \\
\text { Survival" } \\
\text { Development } \\
\text { Bioiuminescence" }\end{array}$ & $\begin{array}{l}\text { Yes } \\
\text { No trend } \\
\text { Yes } \\
\text { Yes } \\
\text { Yes }\end{array}$ & $\begin{array}{l}\text { Perhaps } \\
\text { No trend } \\
\text { Perhaps } \\
\text { Perhaps } \\
\text { Yes }\end{array}$ \\
\hline Phelps & USA & $\begin{array}{l}\text { Mya arenaria } \\
\text { (clam) } \\
\text { Crassostrea gigas } \\
\text { (oyster) }\end{array}$ & $\begin{array}{l}\text { Burrowing } \\
\text { Survival } \\
\text { Metamorphosis" }\end{array}$ & $\begin{array}{l}\text { No trend } \\
\text { No; reverse trend } \\
\text { No; reverse trend }\end{array}$ & $\begin{array}{l}\text { No trend } \\
\text { Yes } \\
\text { Yes }\end{array}$ \\
\hline van den Hurk & Holland & $\begin{array}{l}\text { Crassostrea gigas } \\
\text { (oyster) } \\
\text { Bathyporeia sarsi } \\
\text { (amphipod) }\end{array}$ & $\begin{array}{l}\text { Survival" } \\
\text { Survival } \\
\text { Reburial }\end{array}$ & $\begin{array}{l}\text { No; reverse trend } \\
\text { Yes } \\
\text { Yes }\end{array}$ & $\begin{array}{l}\text { No; bell-shaped curve } \\
\text { Yes } \\
\text { Yes }\end{array}$ \\
\hline
\end{tabular}

Table 5. Summarized sediment toxicity test trends

\begin{tabular}{|c|c|c|c|c|}
\hline \multirow[t]{3}{*}{ Trends: } & \multicolumn{4}{|c|}{ Number of responses $(\%)$} \\
\hline & \multicolumn{2}{|c|}{ At drilling site near platform } & \multicolumn{2}{|c|}{ In German Bight near Elbe River } \\
\hline & $\begin{array}{l}\text { Primary } \\
\text { end-points }\end{array}$ & $\begin{array}{l}\text { Secondary } \\
\text { end-points }\end{array}$ & $\begin{array}{l}\text { Primary } \\
\text { end-points }\end{array}$ & $\begin{array}{l}\text { Secondary } \\
\text { end-points }\end{array}$ \\
\hline Clear trend; higher toxicity & $7 \quad(64 \%)$ & $3(33 \%)$ & $5 \quad(46 \%)$ & $2(22 \%)$ \\
\hline Trend of higher toxicity possible but not certain & $0 \quad 10 \%$ & $0 \quad 10 \%$ & $3(27 \%)$ & $2(22 \%)$ \\
\hline No trendi all stations similar & $2(18 \%)$ & $5(56 \%)$ & $2(18 \%)$ & $5 \quad(56 \%)$ \\
\hline \multirow[t]{2}{*}{ Clear trend; no higher toxicity } & $2(18 \%)$ & $1(11 \%)$ & $1 \quad(9 \%)$ & $0 \quad(0 \%)$ \\
\hline & $11(100 \%)$ & $9(100 \%)$ & $11(100 \%)$ & $9(100 \%)$ \\
\hline
\end{tabular}

Table 6. Summary of information provided by the Sediment Quality Triad. Responses are shown as either positive ( + ) or negative $(-)$, indicating whether or not measurable differences from reference conditions were determined

\begin{tabular}{|lcccl|}
\hline Station(s) & $\begin{array}{c}\text { Chemical } \\
\text { contamination }\end{array}$ & $\begin{array}{c}\text { Laboratory } \\
\text { toxicity }\end{array}$ & $\begin{array}{c}\text { Benthos } \\
\text { alteration }\end{array}$ & Pollution-induced degradation \\
\hline 1 to 3 & + & + & + & Yes. Moderate, decreases 1 to 3 \\
A & - & + & $+?$ & Possible, low; effects due to unmeasured chemicals \\
9 & - & - & + & No. Alteration not due to toxic chemicals \\
to 8 & - & - & & No \\
B to G & & & & \\
\hline
\end{tabular}




\section{INFAUNAL BENTHIC COMMUNITY STRUCTURE}

Descriptions and interpretative analyses of the benthic macrofaunal communities along the German Bight and drilling site transects are provided by Kröncke \& Rachor (1992) and Kröncke et al. (1992), respectively. In the German Bight, differences in sediment type (e.g. Fig. 1B) '...hide possible changes along the gradient due to pollution or eutrophication' (Kröncke \& Rachor 1992). However, stations closest to the Elbe River had the lowest number of individuals and species (least at Stn 1), and increasing numbers of species, individuals and diversity were found offshore. Although Stn 9 benthic infaunal community structure was different from all other stations, this difference was attributed to location and sediment physical characteristics rather than to toxic chemicals. In contrast, Stns $1,2 \& 3^{\prime} \ldots$ seem to have reached the polluted or grossly polluted state, where only a few resistant species are present' (Kröncke \& Rachor 1992).

At the drilling site, sediments had basically the same grain-size and organic carbon content (cf. Fig. 1A); any differences between benthic communities at these stations could not have been attributed to these abiotic factors. Decreasing trends in species number, biomass and total abundance, particularly of deep burrowers, were noted within $1000 \mathrm{~m}$ of the platform and Stn A was clearly separated from all other stations based on cluster analysis, but there were no significant differences between stations (Kröncke et al. 1992). Rather, available evidence indicated that the fauna had recovered from what had previously been readily discernible discharge-related community-level changes (Daan et al. 1990, 1992, de Jong et al. 1991, Heip 1992). Discharge ceased 3 yr previous to this workshop and subsequent storm action had covered the original sediments containing oil and other discharges with a layer of clean material at the time of sampling (Kröncke et al. 1992, Rumohr \& Schomann 1992).

Benthic infaunal communities along both transects showed no clear evidence of major pollution-related impacts such as was observed in the toxicity tests. Although benthic communities nearest to each of the 2 potential sources showed changes that could have been due to toxic contamination, the evidence for such changes did not derive from all methods of data analysis and interpretation. For instance, $A B C$ curves indicated that all drilling site stations '... form part of an undisturbed community', while multivariate analyses indicated '... that there is still a gradient in the macrofauna community structure similar to the one found shortly after the discharge had taken place' (Kröncke et al. 1992). Thus, the benthic macrofauna results suggested changes close to sources but were far from definitive.

\section{INTEGRATIVE ASSESSMENT}

Integrative assessments, reviewed by Chapman et al. (1992a), are defined as investigations involving attempts to integrate measures of environmental quality to make an overall assessment of the status of the system. Such assessments can involve 2 or more of the following components: sediment toxicity tests, sediment chemical analyses, tissue chemical analyses, pathological studies, and community structure studies. The present workshop included all 5 possible components, with particular emphasis on the Sediment Quality Triad (Chapman 1990).

Analyses of Triad data can involve comparisons of RTR values, ranking, and multivariate analyses and, in particular, Mantel's test (Mantel 1967, Legendre \& Fortin 1989). Full details of various methods of Triad data analyses are provided in Chapman (1992). Complex methods of data analyses, derived primarily for situations where contamination and toxicity derive from a variety of sources, were not necessary in the present study where 2 transects were studied with clear point sources. Information provided by comparing sediment toxicity, chemistry and benthic infauna alteration, as discussed above, is summarised in Table 6.

Pollution-induced degradation (defined as positive responses to all 3 Triad components resulting in an adverse change to resident communities including bottom fish and benthic infauna) is only clearly demonstrated at the nearshore German Bight stations and was moderate rather than extreme. Low levels of pollution and degradation may also be occurring in the centre of the drilling site, but this is much less certain. All other drilling site stations and the outermost 6 German Bight stations show no evidence of pollution-induced degradation.

Studies on benthic fish for the 2 areas focused on dab Limanda limanda. Preneoplastic liver lesions and epidermal ulceration in dab were found, not only in nearshore fish but also, by some measures, offshore over the Dogger Bank. The frequency of abnormalities and malformations in fish embryos and larvae in the plankton was elevated in nearshore waters, then declined offshore but increased again over Dogger Bank (Bucke et al. 1992, Cameron \& Berg 1992, Hardy \& Cleary 1992, Vethaak et al. 1992).

\section{STATUS OF NORTH SEA SEDIMENTS}

Previous studies of the effects of drilling platforms in the North Sea (Gray et al. 1990) have shown a gradient of potential effects (as determined solely based on benthic community structure). Similar gradients around drilling platforms occur in other parts of the world (e.g. 
the Gulf of Mexico; Chapman et al. 1991b). The drilling site gradient only showed possible effects at the original source; previous studies (de Jong et al. 1991. Daan et al. 1992) along this gradient have shown contamination, toxicity and benthos alteration (a Triad indicating pollution-induced degradation) extending in 1988 for 500 to $750 \mathrm{~m}$ from the center of drilling. Drilling was exploratory and ceased in 1987. The German Bight gradient showed clear effects close inshore, but a similarly clear decrease offshore.

Sediment contamination and toxicity resulting in pollution can be due to both new and historical contamination. Historical contamination is subject, without new inputs, to natural capping with clean sediments due to storm action, as discussed previously. For instance, Mair et al. (1987) and de Jong et al. (1991) have shown recovery of the macrobenthos in the North Sea following termination of drill-cuttings discharges. The speed and extent of recovery will depend on the extent of effects, which is greatest the longer the source has been operating. In the case of oil platforms, the extent of effects can be up to $1000 \mathrm{~m}$ (Mair et al. 1987, de Jong et al. 1991).

The present study was not comprehensive in that not all areas of the North Sea were studied. However, it is the largest international exercise to date studying the North Sea and lends itself to certain testable hypotheses. Specifically, based on the results of this study it appears that:

(1) sediment pollution is not general in the North Sea area [offshore sediments away from sources are not polluted nor degraded although major depositional areas such as the Norwegian Trench (Becker et al. 1992), which have not been fully investigated, could be polluted];

(2) sediment pollution is generally restricted to the vicinity of point source discharges, in the case of oil platforms on the order of hundreds of meters, and in the case of major rivers on the order of tens of kilometres;

(3) cessation of point-source discharges in offshore areas should result in decreased sediment pollution through natural capping (e.g. storm action: sediments are very mobile; Becker et al. 1992, Rumohr \& Schomann 1992).

In addition, there are certain unresolved issues that require further, but focused study. Dogger Bank sediments are clearly not polluted, yet dab collected from the Dogger Bank appear to show evidence of stress (note that all workshop participants did not agree on this point). Although the Dogger Bank area comprises a coastal front and such fronts have been shown to accumulate contaminants (Tanabe et al. 1991), there is no evidence of such accumulation in Dogger Bank sediments, which are coarse-grained and hence not de- positional. Clearly if this stress exists it cannot be due to sediment contamination. Water column tests conducted during this international study showed no evidence for widespread contamination and toxicity other than in the surface micro-layer (Hardy \& Cleary 1992, Thain 1992). Dab eggs and embryos are found primarily near the surface of the water column (Cameron \& Berg 1992, Rijnsdorp et al. 1992). Reports by Norberg (1990) and Preston \& Merrett (1991) suggest that major air-borne contaminant inputs to the North Sea occur. Norberg (1990) suggests that some of the heaviest airborne contamination occurs at the Dogger Bank. Accordingly, the most likely potential sources of this stress, which merit further research if such stress is confirmed, are:

- surface micro-layer (aerial transport of toxicants resulting in contaminated, toxic waters into which buoyant dab eggs float and where exposure resulting in effects realized in older life-stages occurs);

- dab immigration from other areas closer to sources, such that the dab populations at Dogger Bank are not resident (cf. Rijnsdorp et al. 1992).

One overall conclusion from this international workshop and the new information it has provided is that multi-disciplinary, integrative, broad-scale studies, although relatively expensive, are important because they:

(1) determine and prioritise problem areas;

(2) provide managers, regulators and the public with the best possible information for decision-making and resource allocation.

Such integrative assessments, which include the Sediment Quality Triad, are recommended for existing and future marine pollution assessments.

Acknowledgements. I thank the large number of individuals who contributed to the success of the workshop, especially Tony Stebbing and Martin Carr of PML, and Simon Wilson of ICES. I particularly thank Carlo Heip for selflessly sharing his benthic infaunal data early in the preparation of this paper. Partial funding for this work was provided by EVS Consultants, ICES and a TIP grant from the government of Canada. External peer review was provided by Drs W. Adams (ABC Laboratories) and R. Swartz (U.S. EPA).

\section{LITERATURE CITED}

Alden, R. W. III (1992). Uncertainty and sediment quality assessments: I. Confidence limits for the triad. Environ. Toxicol. Chem. 11,637-644

Ankley, G. T., Katko, A., Arthur, J. W. (1990). Identification of ammonia as an important sediment-associated toxicant in the Lower Fox River and Green Bay, Wisconsin. Environ. Toxicol. Chem. 9: 313-322

Becker, G. A., Dick, S., Dippner, J. W. (1992). Hydrography of the German Bight. Mar. Ecol. Prog. Ser. 91: 9-18

Bucke, D., Vethaak, A. D., Lang, T (1992). Quantitative as- 
sessment of melanomacrophage centres (MMCs) in dab Limanda limanda along a pollution transect in the German Bight. Mar. Ecol. Prog. Ser 91: 193-196

Butler, R., Chapman, P. M., van den Hurk, P., Roddie, B., Thain, J. E. (1992). A comparison of North American and Western European oyster embryo-larval toxicity tests on North Sea sediments. Mar. Ecol. Prog. Ser. 91: 245-251

Cameron, P., Berg, J. (1992). Morphological and chromosomal aberrations during embryonic development in dab Limanda limanda. Mar. Ecol. Prog. Ser. 91: 163-169

Chapman, P. M. (1986a). Sediment quality criteria from the Sediment Quality Triad - an example. Environ. Toxicol. Chem. 5: 957-964

Chapman, P. M. (1986b). Sediment bioassay tests provide toxicity data necessary for assessment and regulation. In: Geen, G. H., Woodward, K. L. (eds.) Proc. 11th Annual Aquatic Toxicity Workshop. Can. Tech. Rept. Fish. Aquat. Sci. 1480, p. $178-197$

Chapman, P. M. (1988). Marine sediment toxicity tests. In: Lichtenberg, J. J., Winter, F. A., Weber, C. I., Fradkin, L. (eds.) Chemical and biological characterization of sludges, sediments, dredge spoils, and drilling muds. ASTM STP 976. American Society for Testing and Materials, Philadelphia, p. 391-402

Chapman, P. M. (1989). Current approaches to developing sediment quality criteria. Environ. Toxicol Chem. 8: $589-599$

Chapman, P. M. (1990). The sediment quality triad approach to determining pollution-induced degradation. Sci. tot. Environ. 97/98: 815-825

Chapman, P. M. (1992). Sediment Quality Triad approach. In: Sediment classification methods compendium, Chap. 10. Watershed Protection Division, U.S. Environmental Protection Agency, Washington, D.C. (update of June 1989 version). EPA 823-R-92-006

Chapman, P. M., Romberg, G. P., Vigers, G. A. (1982). Design of monitoring studies for priority pollutants. I Water Pollut. Control Fed. 54: 292-297

Chapman, P. M., Barrick, R. C., Neff, J. M., Swartz, R. C. (1987a). Four independent approaches to developing sediment quality criteria yield similar values for model contaminants. Environ. Toxicol. Chem. 6: 723-725

Chapman, P. M., Dexter, R. N., Long, E. R. (1987b). Synoptic measures of sediment contamination, toxicity and infaunal community structure (the Sediment Quality Triad) in San Francisco Bay. Mar. Ecol. Prog. Ser. 37: 75-96

Chapman, P. M., Long, E. R., Swartz, R. C., DeWitt, T. H., Pastorok, R. (1991a). Sediment toxicity tests, sediment chemistry and benthic ecology do provide new insights into the significance and management of contaminated sediments - a reply to Robert Spies. Environ. Toxicol. Chem. 10: 1-4

Chapman, P. M., Power, E. A., Dexter, R. N., Andersen, H. B. (1991b). Evaluation of effects associated with an oil platform, using the Sediment Quality Triad. Environ. Toxicol. Chem. 10: 407-424

Chapman, P. M., Power, E. A., Burton, G. A. Jr (1992a). Integrative assessments in aquatic ecosystems. In: Burton, G. A. Jr (ed.) Contaminated sediment toxicity assessment. Lewis Publishers, Chelsea, Michigan, p. 313-340

Chapman, P. M., Swartz, R. C., Roddie, B., Phelps, H. L., van den Hurk, P., Butler, R. (1992b). An international comparison of sediment toxicity tests in the North Sea. Mar. Ecol. Prog. Ser. 91. 253-264

Cofino, W. P., Smedes, F., de Jong, S. A., Abarnou, A., Boon, J. P., Oostingh, I., Davies, I. M., Klungsøyr, J., Wilhelmsen, S., Law, R. J., Whinnett, J. A., Schmidt, D., Wilson, S.
(1992). The chemistry programme. Mar. Ecol. Prog. Ser. 91: $47-56$

Cross, S. F., Boyd, J. M., Chapman, P. M., Brinkhurst, R. O. (1991). A multivariate approach for defining spatial impacts using the Sediment Quality Triad. In: Chapman, P. M., Bishay, F. S., Power, E. A., Hall, K., Harding, L., McLeay, D., Nassichuk, M., Knapp, W. (eds.) Proc. 17th Annual Aquatic Toxicity Workshop: November 5-7, 1990 , Vancouver, B.C. Can. Tech. Rept. Fish. Aquat. Sci. 1774 : 886

Daan, R., Lewis, W. E., Mulder, M. (1990). Biological effects of discharged oil-contaminated drill cuttings in the North Sea. NIOZ-Rapport 1990-5: 79 pp

Daan, R., van het Groenewoud, H., de Jong, S. A., Mulder, M. (1992). Physico-chemical and biological features of a drilling site in the North Sea, 1 year after discharges of oilcontaminated drill cuttings. Mar. Ecol. Prog. Ser. 91: $37-45$

de Jong, S. A., Zevenboom, W., van het Groenewoud, H. Daan, R. (1991). Short and long term effects of discharged OBM cuttings, with and without previous washing, tested in field and laboratory studies on the Dutch Continental Shelf, 1985-1990. Unpubl. manuscript, Dutch Ministry of Transport and Public Works, North Sea Directorate, Rijswik, The Netherlands

Dutch Ministry of Transport and Public Works (1989). Water in the Netherlands: a time for action. National policy document on water management, $68 \mathrm{pp}$.

Gray, J. S., Clarke, K. R., Warwick, R. M., Hobbs, G. (1990). Detection of initial effects of pollution on marine benthos: an example from the Ekofisk and Eldfisk oilfields, North Sea. Mar. Ecol. Prog. Ser. 66: 285-299

Hardy, J. T., Cleary, J. (1992). Surface microlayer contamination and toxicity in the German Bight. Mar. Ecol. Prog. Ser. 91: $203-210$

Heip, C. (1992). Benthic studies: summary and conclusions. Mar. Ecol. Prog. Ser, 91: 265-268

Kröncke, 1., Duineveld, G. C. A., Raak, S., Rachor, E., Daan, R. (1992). Effects of a former discharge of drill cuttings on the macrofauna community. Mar. Ecol. Prog. Ser. 91: 277-287

Kröncke, I., Rachor, E. (1992). Macrofauna investigations along a transect from the inner German Bight towards the Dogger Bank. Mar. Ecol. Prog. Ser. 91: 269-276

Legendre, P., Fortin, M.-J. (1989). Spatial pattern and ecological analysis. Vegetatio 80: $107-138$

Long, E. R. (1989a). The use of the Sediment Quality Triad in classification of sediment contamination. In: Contaminated marine sediments - assessment and remediation. National Research Council, National Academy Press, Washington, D.C., p. 78-93

Long, E. R. (1989b). Comparison of sediment quality criteria developed from effects-based approaches: do we have convergence or divergence? In: Proceedings, Oceans '89, The Global Ocean, Vol. 2: Ocean pollution. Oceanic Engineering Society of the Institute of Electrical and Electronics Engineers, IEEE Pub. No. 89CH2780-5, p. $415-420$

Long, E. R., Chapman, P. M. (1985). A sediment quality triad: measures of sediment contamination, toxicity and infaunal community structure in Puget Sound. Mar. Pollut. Bull. 16: 405-415

Long, E. R., Morgan, L. G. (1990). The potential for biological effects of sediment-sorbed contaminants tested in the National Status and Trends Program. U.S. Dept. of Commerce, NOAA Tech. Memo. NOS OMA 52

Mair, J, McD., Matheson, I., Appelbee, J. F. (1987). Offshore macrobenthic recovery in the Murchison Field following 
the termination of drill-cuttings discharges. Mar. Pollut. Bull. 18: 628-634

Mantel, N. (1967). The detection of disease clustering and a generalized regression approach. Cancer Res. 27: $200-209$

Netherlands (1983). Soil pollution clean-up guidelines. Interim Act on Soil Pollution Clean-Up, Ministry of Housing. Zoning and Environmental Management, July 1983

Norberg, S. N. (1990). Is the North Sea really dying? Ocean '99 1: 11-13

Preston, M. R., Merrett, J. (1991). The distribution and origins of the hydrocarbon fraction of particulate material in the North Sea atmosphere. Mar. Pollut. Bull. 22: 516-522

PSDDA (1989). Management plan report - Unconfined open water disposal of dredged material, Phase II (North and South Puget Sound). Puget Sound Dredged Disposal Analysis Program Report Series, U.S. Army Corps of Engineers, Seattle, Washington

PTI Environmental Services (1988). Sediment quality values refinement: Tasks 3 and 5-1988 update and evaluation of Puget Sound AET U.S. Environmental Protection Agency, Region 10, Seattle, Washington
Rijnsdorp, A. D., Vethaak, A. D., van Leeuwen, P. I. (1992). Population biology of dab Limanda Limanda in the southeastern North Sea. Mar. Ecol. Prog. Ser. 91: 19-35

Rumohr, H., Schomann, H. (1992). REMOTS sediment profiles around an exploratory drilling rig in the southern North Sea. Mar. Ecol. Prog. Ser. 91: 303-311

Stebbing, A. R. D., Dethlefsen, V. (1992). Introduction to the Bremerhaven Workshop on Biological Effects of Contaminants. Mar. Ecol. Prog. Ser. 91: 1-8

Tanabe, S., Nishimura, A., Hanaoka, S., Yanagi, T., Takeoka, H., Tatsukawa, R. (1991). Persistent organochlorines in coastal fronts. Mar. Pollut. Bull. 22: 344-351

Thain, J. E. (1992). Use of the oyster Crassostrea gigas embryo bioassay on water and sediment elutriate samples from the German Bight. Mar. Ecol. Prog. Ser. 91. 211-213

Vethaak, A. D., Bucke, D., Lang, T., Wester, P. W., Jol, J., Carr, M. (1992). Fish disease monitoring along a pollution transect: a case study using dab Limanda limanda in the German Bight. Mar. Ecol. Prog. Ser. 91: 173-192

WDOE (1991). Sediment management standards. Chap. 173-204 WAC, Washington State Department of Ecology, Olympia, Washington 